\title{
An Affordable Knee Arthroscopy Simulator
}

\section{Um Simulador de Artroscopia de Joelho Acessível}

\author{
Paul André Alain Milcent ${ }^{1}$ (iD \\ Alexandre Roberto Roman Coelho ${ }^{\mathrm{I}}$ (ID \\ Sthéphano Pellizzaro Rosa ${ }^{1}$ (iD \\ Ygor Luiz Degraf da Fonseca ${ }^{\mathrm{I}}$ (D) \\ Andressa Zabudovski Schroeder ${ }^{\mathrm{I}}$ (D) \\ Edmar Stieven Filho ${ }^{1}$ (i)
}

\section{KEYWORDS}

- Arthroscopy.

- Simulation.

- Simulation training.

- Meniscus.

- Knee.

Introduction: The objective of this study is to describe a model of knee arthroscopy simulator that is affordable, low-cost and easily reproducible, aiming to enable the diffusion of more effective active teaching and training methodologies. Methods: For the creation of the arthroscopic camera, an endoscopic camera for mobile phones and computers model SXT-5.OM manufactured by KKMOON were used. The camera was introduced in a metal tube, which was coupled to a set of three $20 \mathrm{~mm}$ PVC hydraulic connectors to simulate the handle and sleeve of the arthroscope. The camera has a resolution of $1280 \times 720$ pixels and is equipped with six built-in white LED lamps, simulating and eliminating the need to use an additional light source. The knee model was developed using a PVC pipe fixed on a wooden support, to which synthetic femur and tibia models were affixed. Four three-centimeter diameter holes, compatible with the standard arthroscopic portals, were made in the body of the PVC pipe. For the menisci, a model was made out of modeling clay (Corfix $)$, until the anatomical structures were close to the real ones. The model consists of both menisci and the intercondylar eminence, simulating the proximal tibial articular surface. The model made out of modeling clay was the basis for the production of a thin Crystal Polyester Resin mold. Using the resin mold, the meniscal models were made of Silicone Rubber Type II, widely used in industry and crafts. Results: A functional and reproducible simulator was obtained, consisting of a knee model and an arthroscopic camera. The simulator works adequately adapted to a TV, monitor or computer, and allows the simulation of diagnostic procedures, meniscectomy and meniscoplasty. Conclusion: It is possible to develop a knee arthroscopy simulator, with components available in local and electronic commerce, at a cost of approximately $R \$ 300$. 


\section{RESUMO}

\section{PALAVRAS-CHAVE}

- Artroscopia.

- Simulação.

- Treinamento por simulação.

- Menisco.

- Joelho.

Introdução: O objetivo deste trabalho é descrever um modelo de simulador de artroscopia de joelho acessível, de baixo custo e facilmente reprodutível, com o intuito de permitir a difusão de metodologias de ensino ativas e treinamento mais eficazes. Métodos: Para a confecção da câmera artroscópica, foi utilizada uma câmera endoscópica para celulares e computadores modelo SXT-5.0M da fabricante KKMOON. Introduziu-se a câmera em um tubo de metal, o qual foi acoplado a um conjunto de três conectores hidráulicos de PVC de $20 \mathrm{~mm}$ para simular a empunhadura e camisa do artroscópio. A câmera tem resolução de $1.280 \times 720$ pixels e seis lâmpadas brancas de LED embutidas, simulando e dispensando a utilização de uma fonte de luz auxiliar. O modelo de joelho foi confeccionado a partir de um cano de PVC fixado em uma base de madeira, ao qual se acoplou um modelo de fêmur e tíbia sintéticos. No corpo do cano de PVC, foram confeccionadas quatro perfurações de $3 \mathrm{~cm}$ de diâmetro, compatíveis com os portais artroscópicos habituais. Para os meniscos, fez-se um modelo em massa de modelar (Corfix $\left.{ }^{\circledast}\right)$, até que as estruturas anatômicas estivessem próximas do real. O modelo é composto por ambos os meniscos e pela eminência intercondilar, simulando a superfície articular proximal da tíbia. O modelo de massa de modelar foi a base para um molde em resina poliéster cristal fina. Com o molde em resina, os modelos meniscais foram confeccionados com borracha de silicone para moldes do tipo II, amplamente utilizados na indústria e no artesanato. Resultados: Obteve-se um simulador funcional e reprodutível, composto de um modelo de joelho e uma câmera artroscópica. Tal simulador funciona adequadamente adaptado a uma TV, um monitor ou computador e permite a simulação de procedimentos diagnósticos, meniscectomia e meniscoplastia. Conclusão: É possível desenvolver um simulador de artroscopia de joelho, com peças disponíveis em comércio local e eletrônico, por um valor aproximado de $R \$ 300,00$.

Received on $10 / 22 / 19$

Accepted on $12 / 10 / 19$

\section{INTRODUCTION}

The development of minimally invasive approaches has allowed great advances in the field of surgery, decreasing patient morbidity and improving postoperative results. In orthopedics, the popularization of arthroscopy since the mid-1980s has promoted a revolution in the treatment of intra-articular pathologies, being currently one of the most frequently performed surgical procedures worldwide. In this type of approach, the visualization of internal structures and surgical instruments is carried out with a camera, with such materials being introduced into the joint through small skin incisions ${ }^{1}$.

Due to the necessary skills and the particularities of the technique, the learning curve for arthroscopy can be a long one, making its training methodology a target of constant attention. In the traditional training method, the student watches surgeries performed by more experienced surgeons and gradually performs more complex procedures under supervision $^{2,3}$. This approach, however, has a number of disadvantages, both due to the increased risks and surgical time, as well as the patients' discomfort in being treated by surgeons in training. There are also restrictions regarding the number of doctors who can be trained in this condition, given the limited number of people in the operating room ${ }^{1}$.

Alternatives to arthroscopic training in vivo include the use of cadavers, animals, dry models and virtual reality. Cadaveric models, despite being the most reliable ones, have problems with cost, availability and storage, as well as the potential biological risk ${ }^{4}$. Animal experiments have logistical difficulties, such as handling and disposal, in addition to ethical issues and anatomical differences. Virtual reality models can simulate the three-dimensional environment of arthroscopy, but its main limiting factor is the high cost and tactile feedback. In this context, the use of dry models appears as a viable alternative, while it is possible to reduce the learning curve and improve surgical skills, being comparable to training on human cadavers ${ }^{5}$.

Learning in simulators has been identified as a reliable way to improve orthopedic training ${ }^{6,7}$. The simulation in arthroscopy is able to improve surgical skills, allowing training outside the operating room and even the testing of new instruments, but the cost of simulators is an important barrier for many realities ${ }^{8-10}$.

The objective of this work is to describe an affordable model of knee arthroscopy simulator, of low cost and easily reproducible, aiming to allow the dissemination of active teaching methodologies and more effective training.

\section{MATERIALS AND METHODS}

Camera and optics

For the manufacture of the arthroscopic camera, we used an endoscopic camera for cell phones and computers model SXT-5.0M, manufactured by KKMOON. This choice was made due to its availability, costs, dimensions and malleability, allowing the development of an instrument functionally close to the usual arthroscope with an approximate price of $\mathrm{R} \$ 50$.

The camera has a resolution of $1280 \times 720$ pixels and has six built-in white LED lamps, simulating and eliminating the need to use an additional light source. Its extremity has a metallic coating for greater durability, which was bent at an angle of $30^{\circ}$ to simulate the usual inclination angle of an arthroscope. The camera was inserted into an aluminum tube measuring $5 \mathrm{~mm}$ in diameter and $25 \mathrm{~cm}$ in length (simulating the body of the arthroscope), aligning its extremities and fixing them with acrylic adhesive glue. To fix the camera cable along the interior of the metal tube, three perforations were made with a drill, and three small metal screws were inserted (alternatively, the tube can be filled with acrylic adhesive

REVISTA BRASILEIRA DE EDUCAÇÃO MÉDICA

2 44 (1) : e037; 2020 
glue, also offering good fixation).

To simulate the arthroscope handle and sleeve, the other end of the metal tube was inserted in a set of three $20 \mathrm{~mm}$ PVC hydraulic connectors ( $90^{\circ}$ " $\mathrm{T}$ " connector, weldable adapter and $90^{\circ}$ knee), fixing the structures with Polyester Crystal Resin. Finally, the camera was connected to a monitor, using a USB adapter that comes with the camera (Figure 1).

Knee model

The simulator was designed to mimic a right knee. The material used for creating the knee was a PVC pipe, called in the construction industry by the namesake " $90^{\circ}$ PVC Knee", $150 \mathrm{~mm}$ with a $75 \mathrm{~mm}$ view, where 150 $\mathrm{mm}$ refers to the gauge of the pipe extremities and 75 to a round orifice on top, allowing light to enter (Figure 2).

The proximal end of the tube was closed with a specific PVC plug called CAP $150 \mathrm{~mm}$, to which a model of the right synthetic femur was affixed, forming the proximal part of the knee. The distal extremity was closed with a wooden base, to which a right synthetic proximal tibia was fixed, using screws and an "L"-shaped metal plate. In the body of the PVC pipe, four perforations were made measuring three centimeters in
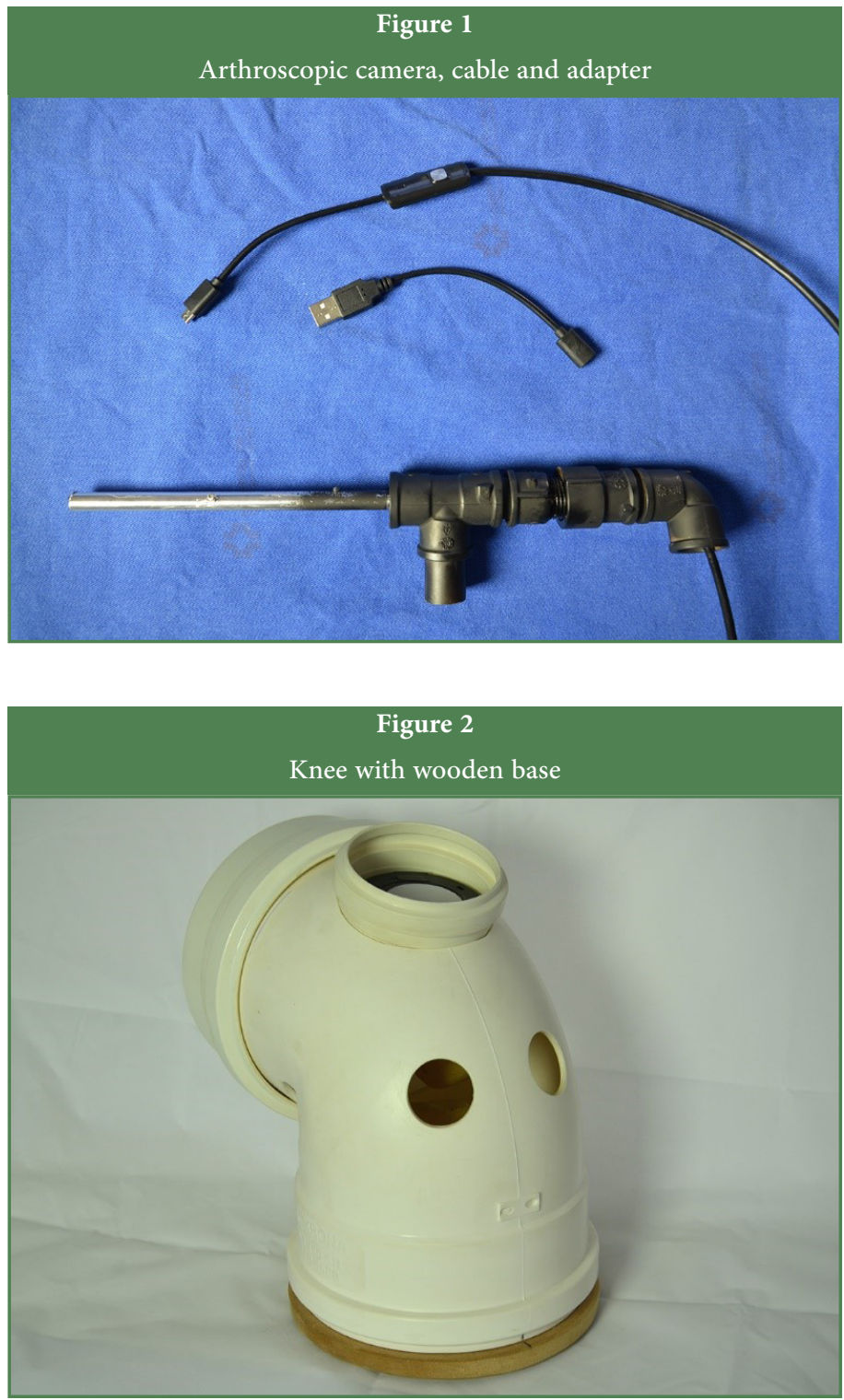

diameter, compatible with the anterolateral, anteromedial, posterolateral and posteromedial portals. The tibia and femur were acquired through electronic commerce (Nacional Ossos ${ }^{\circledR}$ ) (Figure 3).

\section{The meniscus}

For the menisci, a modeling clay (Corfix ${ }^{\circ}$ ) model was made, until the anatomical structures were close to the real one. The model consists of both menisci and the intercondylar eminence, simulating the proximal tibial articular surface. The model made of modeling clay was the basis for a fine Polyester Crystal Resin mold (Figure 4).

Using the resin mold, the meniscal models were made with Silicone Rubber for type II molds, widely used in industry and crafts.

The models were fixed at the base of the proximal tibia using four metallic nails (Figure 5).

\section{RESULT}

The simulator works adequately adapted to a $\mathrm{TV}$, monitor or computer, using the free version of the Debut Video Capture ${ }^{\diamond}$ software (Figure 6).
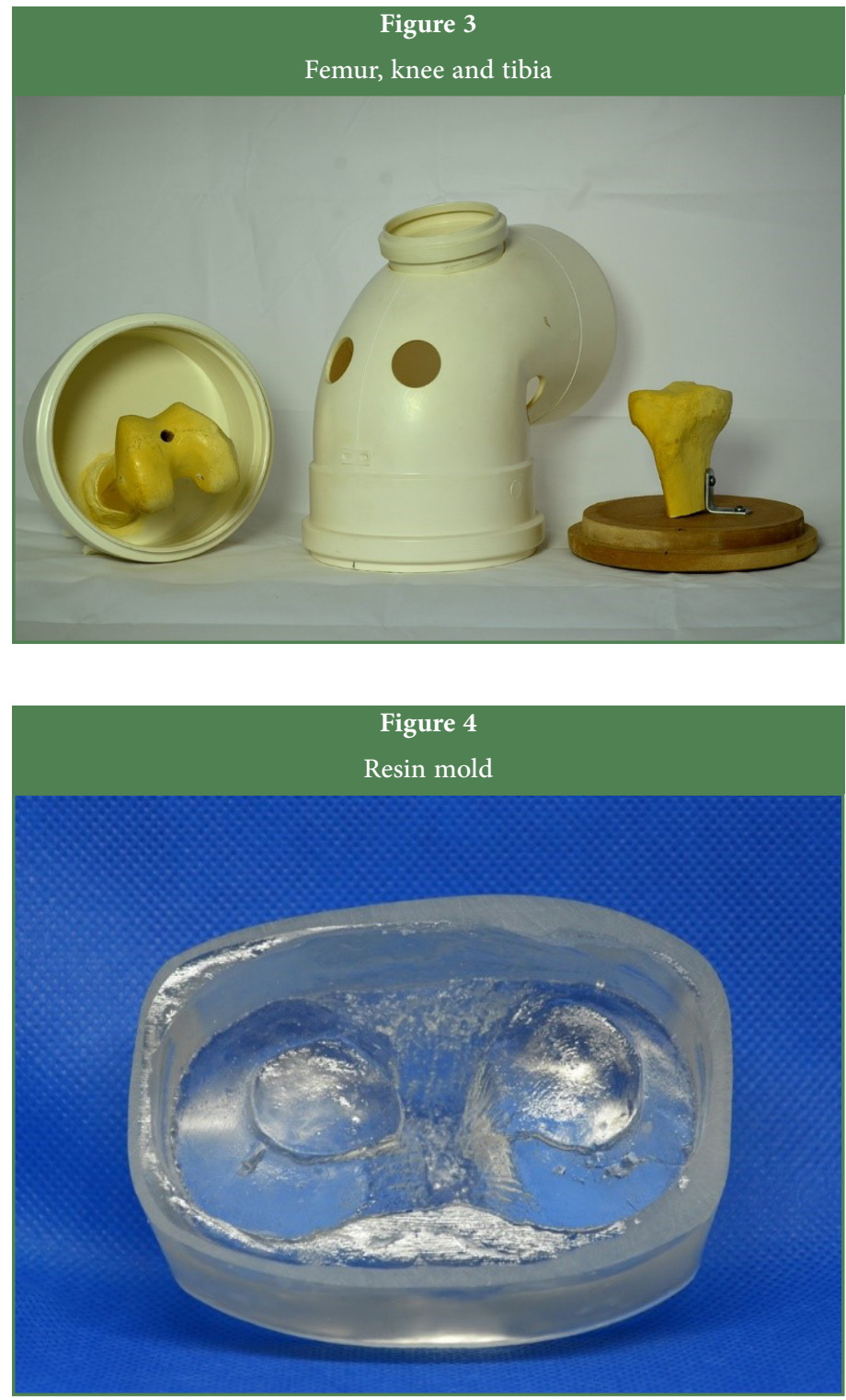

\begin{tabular}{l|l}
3 & REVISTA BRASILEIRA DE EDUCAÇÃO MÉDICA \\
\hline 44 (1) : e037; 2020
\end{tabular} 

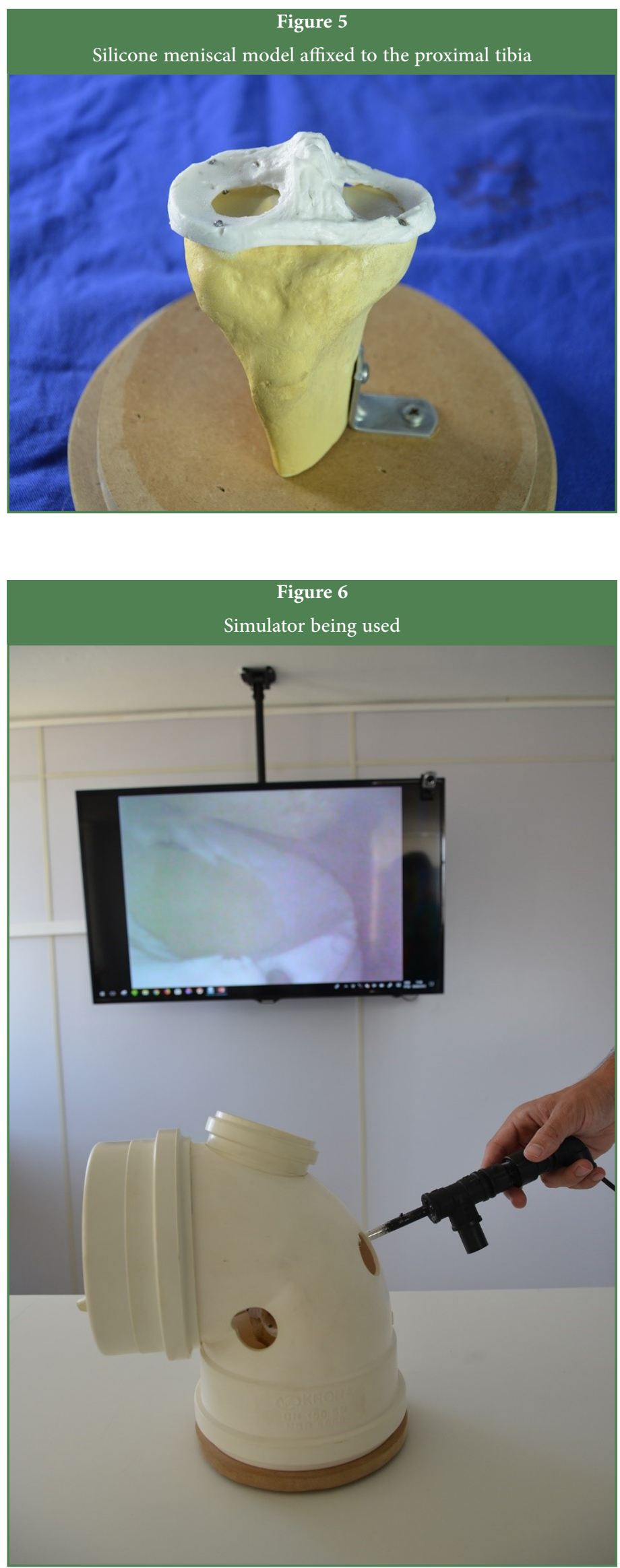

The costs of the simulator, including the synthetic knee model, the camera with its adapter and a variety of materials for the construction of the external structure and menisci, were approximately of $R \$ 310.00$, according to Table 1 .

\section{DISCUSSION}

In arthroscopy, the acquisition of images is performed through an optical system, associated with a video camera and a light source. The optical system consists of a metal tube containing a series of lenses. The lens of the arthroscopy optics has an angulation in relation to its long axis aiming to increase the surgeon's field of view (when rotating the optics, the joint is traversed at the ratio of the established angle). Although there are optics from zero to $70^{\circ}$ of angulation, the most used is $30^{\circ 11}$. In this case, we simulated the optics angle by opening the endoscopic camera and bending its extremity. The process of creating the final angulation is one of the most painstaking processes. One possibility would be to build a camera simulator leaving the optics at $0^{\circ}$. It would not be as close to reality, but for basic training it may be enough.

One of the problems with the developed camera model is that it does not have the arthroscopic optics lens set. This makes the optical rotation movements not possible in the simulated camera. Even with this limitation, we think it is important to maintain the simulated camera, as it is the most expensive part and has low durability. The substitution by a low-cost material can bring peace of mind during the training of inexperienced individuals, especially when you have a large number of individuals under supervision at the same time.

In the initial process of preparing the simulated camera, we acquired an car reverse camera, which provided us with an inverted image of what was being captured. This standoff was solved by replacing the device with a front-facing car camera, but this one had limitations regarding the fact that the image is analogical, requiring the utilization of adapters to use digital monitors. Moreover, the car camera requires an external light source.

We started to test a series of webcams, but we came up against the issue of large dimensions and the lack of possibility of having an angulation at its extremity. Therefore, we consider that webcams, in general, do not meet this purpose. At a second step, we used car cameras. The images were good, but the movements on the monitor were confusing. We noticed that

\begin{tabular}{|lc|}
\multicolumn{1}{c}{$\begin{array}{c}\text { Table } 1 \\
\text { Simulator cost }\end{array}$} & \\
\hline \multicolumn{1}{|c|}{ Item } & Value (R\$) \\
\hline Synthetic knee anatomical model & 100.00 \\
\hline Endoscopic camera for cell phones + adapter & 50.00 \\
\hline Aluminum tube 5 mm & 20.00 \\
\hline PVC pipes and connectors & 60.00 \\
\hline Acrylic adhesive glue & 15.00 \\
\hline Polyester crystal resin & 25.00 \\
\hline Silicone rubber for type II molds & 30.00 \\
\hline Nails and screws & 5.00 \\
\hline Wooden boards & 5.00 \\
\hline
\end{tabular}


we were using reverse cameras, which of course made the movements inverted. We purchased front-facing car cameras, which solved the problem, but there were still non-favorable points; one of them was that, despite having a much smaller dimension than a webcam, it was still large for the standard of an arthroscopic camera. The second is the fact that it is an analogical camera, so one needs a converter to connect it to a digital monitor. The third point is that it does not have its own light source, requiring the addition of an auxiliary light. But for those who want to use a simulator connected to an analogical monitor (old televisions) this could be a good option.

Finally, the choice of the endoscopic camera for cell phones allowed $30^{\circ}$ of angulation, and has its own light source powered by the same USB cable that conducts the image. In addition, it has dimensions close to that of the original camera, maintaining the desired characteristics of low cost and availability. We use an SXT-5.0M endoscopic camera manufactured by KKMOON, but we believe that any endoscopic camera for cell phones will be adequate for this use.

In an open surgery, the surgeon manipulates instruments under direct visualization. In arthroscopic surgery, on the other hand, the surgeon must navigate the instruments within the joint with visualization through images projected on a screen. This process of finding both camera and instrument, without looking directly at them, is called triangulation ${ }^{11}$. Arthroscopic manipulation should be performed with caution, since the amplified dimension of the monitor can mislead the surgeon, leading to iatrogenic injuries, such as damage to articular cartilage ${ }^{12}$. Therefore, the arthroscopy requires specific training, which includes the visual ability to interpret three-dimensional structures from two-dimensional and enlarged images, in addition to coordination for triangulation ${ }^{13-16}$. This training can be performed in the simulator, saving learning time in the operating room and in the patient.

The use of simulators can allow this learning in a safe environment, but objective and standardized measures of performance and development evaluation still need to be validated. Although it may seem logical that arthroscopic simulators are useful in the development of psychomotor skills, the transition from simulation to in vivo surgery still lacks data.

Our model of knee arthroscopy simulator has its affordability as the main positive point. The simpler a simulator, the easier it is to incorporate it into daily training ${ }^{17}$. Another important aspect is to maintain the acquired skills with any form of training. It is known that although activities with simulators are able to improve skills, after one year this effect is $\operatorname{lost}^{18}$. Thus, when the simulator is readily available, there is a greater chance of ongoing training in medical education services.

Another work is available in the literature that developed an arthroscopic simulator based on the same affordability principles, but they used a webcam and a cardboard box, instead ${ }^{8}$. When comparing our simulator with that made with a cardboard box, one can say that both have affordability as the objective, but the cardboard box is more accessible than the synthetic pieces of femur and tibia ${ }^{8}$. The advantage of the simulator with synthetic parts would be the greatest similarity in relation to the real orthopedic procedures, in this specific case, knee arthroscopy. The cardboard box would produce a more comprehensive training procedure, while in the knee simulator it is more specialized. Thus, one can choose the model to be used, according to the training intention. This choice will be based on subjective data, since there are no standards in the literature for how simulator training for arthroscopic procedures should be.

Silicone was chosen to create the meniscus models because it has a consistency very similar to that of the meniscus. The making of the mold is a laborious process, but it is made only once. Once the molds are available, they can be reused indefinitely. A person with good artistic skills can solve this problem.

An alternative solution would be to print the mold on a $3 \mathrm{D}$ printer. For that we would need the mold file and the printer. In this case, we would also need the tibia to be printed, as the meniscus mold and tibia must have compatible sizes. We believe that access to a $3 \mathrm{D}$ printer, as well as the skills needed to operate it, are still factors that decrease the affordability. Nevertheless, for many realities and for the near future, it will be a good option. A final alternative is to purchase meniscus models, but this would increase the cost of training.

We cannot envision the possibility of producing alternatives similar to handpieces, such as the probe, grasper forceps and arthroscopic scissors, which is why the use of these original instruments is suggested. We also believe that a synthetic simulator limits learning to certain surgical steps. Points such as patient access and positioning are not possible to be trained through this method. Finally, a future validation of the simulator as a training instrument is necessary.

\section{CONCLUSION}

It is possible to develop a knee arthroscopy simulator, with parts available in local and electronic commerce, for approximately $\mathrm{R} \$ 300$.

\section{REFERENCES}

1. Bayona S, Espadero J, Pastor L, Fernandez-Arroyo JM. A lowcost arthroscopy surgery training system. In: 3rd International Conference on Visualization, Imaging and Image Processing; 2003; Benalmadena, Spain. Benalmadena, Spain: Iasted; 2003 [access in 6 jun 2019]. Available from: http://insightarthrovr.gmv.com/noticias_ publicaciones/articulos/art-IAESTED.pdf.

2. Insel A, Carofino B, Leger R, Arciero R, Mazzocca AD. The development of an objective model to assess arthroscopic performance. J Bone Joint Surg Am 2009;91(9):2287-95.

3. Gorman PJ, Meier AH, Krummel TM. Simulation and virtual reality in surgical education: real or unreal? Arch. surg. 1999;134(11):1203-8.

4. Butler A, Olson T, Koehler R, Nicandri G. Do the skills acquired by novice surgeons using anatomic dry models transfer effectively to the task of diagnostic knee arthroscopy performed on cadaveric specimens? J Bone Joint Surg Am 2013;95(3):e15(1-8).

5. Anastakis DJ, Regehr G, Reznick RK, Cusimano M, Murnaghan J, Brown M, et al. Assessment of technical skills transfer from the bench training model to the human model. Am. j. surg. 1999;177(2):167-70.

6. Cannon WD, Garrett Jr WE, Hunter RE, Sweeney HJ, Eckhoff DG, Nicandri GT, et al. Improving residency training in arthroscopic knee surgery with use of a virtual-reality simulator. A randomized blinded study. J Bone Joint Surg Am 2014;96(21):1798-806.

7. Aïm F, Lonjon G, Hannouche D, Nizard R. Effectiveness of virtual reality training in orthopaedic surgery. Arthroscopy 2016;32(1):224-32.

8. Arealis G, Holton J, Rodrigues JB, Sagkrioti M, Snow M, Hamlet M,

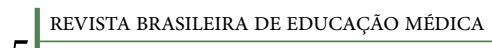

5 44 (1) : e037; 2020 
et al. How to build your simple and cost-effective arthroscopic skills simulator. Arthrosc Tech 2016;5(5):e1039-e1047.

9. Frank RM, Erickson B, Frank JM, Bush-Joseph CA, Bach Jr BR, Cole $\mathrm{BJ}$, et al. Utility of modern arthroscopic simulator training models. Arthroscopy 2014;30(1):121-33.

10. Rebolledo BJ, Hammann-Scala J, Leali A, Ranawat AS. Arthroscopy skills development with a surgical simulator: a comparative study in orthopaedic surgery residents. Am. j. sports med. 2015;43(6):1526-9.

11. Hollands RJ, Trowbridge EA. A virtual reality training tool for the arthroscopic treatment of knee disabilities. Maidenhead, UK: Conf. Disability, Virtual Reality \& Assoc. Tech.; 1996 [access in 6 jun 2019]. Available from: http://www.icdvrat.org/1996/papers/1996_16.pdf.

12. Bamford DJ, Paul AS, Noble J, Davies DR. Avoidable complications of arthroscopic surgery. J R Coll Surg Edinb 1993;38(2):92-5.

13. Pedowitz RA, Esch J, Snyder S. Evaluation of a virtual reality simulator for arthroscopy skills development. Arthroscopy 2002;18(6).

14. Hodgins JL, Veillette C. Arthroscopic proficiency: methods in evaluating competency. BMC med. educ. 2013;13.

15. Obdeijn MC, Bavinck N, Mathoulin C, van der Horst CM, Schijven MP, Tuijthof GJ. Education in wrist arthroscopy: past, present and future. Knee surg. sports traumatol. arthrosc. 2015;23(5):1337-45.

16. Jackson RW. The introduction of arthroscopy to North America. Clin. orthop. relat. res. 2000;(374):183-6.
17. Braman JP, Sweet RM, Hananel DM, Ludewig PM, Van Heest AE. Development and validation of a basic arthroscopy skills simulator. Arthroscopy 2015;31(1):104-12.

18. Dunn JC, Belmont PJ, Lanzi J, Martin K, Bader J, Owens B, et al. Arthroscopic shoulder surgical simulation training curriculum: transfer reliability and maintenance of skill over time. J. surg. educ. 2015;72(6):1118-23.

\section{AUTHORS' CONTRIBUTIONS}

All authors contributed to collection, analyzing and data interpreting. Also, all authors prepared the manuscript and did critical review.

\section{CONFLICTS OF INTEREST}

The authors have no conflicts of interest.

\section{ADDRESS FOR CORRESPONDENCE}

Edmar Stieven Filho. Complexo Hospital de Clínicas, Universidade Federal do Paraná, $6^{\circ}$ andar, Ortopedia e Traumatologia, Rua General Carneiro, 181, Alto da Glória, Curitiba, PR, Brasil. CEP: 80060-900.

E-mail: filho2000@gmail.com 